\title{
The effect of response to heat stress, parity, breed and breeding region on somatic cell count in dairy cattle
}

\author{
Vesna Gantner1, Božidarka Marković², Mirna Gavran', Marcela Šperanda1, \\ Denis Kučević ${ }^{3}$, Maja Gregić ${ }^{1 *}$, and Tina Bobić ${ }^{1}$ \\ ${ }^{1}$ Department for Animal Production and Biotechnology, Faculty of Agrobiotechnology Osijek, University of Josip \\ Juraj Strossmayer of Osijek, Croatia \\ ${ }^{2}$ Department of Livestock Science, Biotechnical Faculty, University of Montenegro, Podgorica, Montenegro \\ ${ }^{3}$ Department of Animal Science, Faculty of Agriculture, University of Novi Sad, Serbia
}

GANTNER, V., B. MARKOVIĆ, M. GAVRAN, M. ŠPERANDA, D. KUČEVIĆ, M. GREGIĆ, T. BOBIĆ: The effect of response to heat stress, parity, breed and breeding region on somatic cell count in dairy cattle. Vet. arhiv 90, 435-442, 2020.

\section{ABSTRACT}

With the aim of determining the effect of response to heat stress, parity, breed and breeding region on somatic cell count (SCC) in dairy cattle, the individual test-day records of dairy cows collected from 2005 to 2012 in regular milk recording (AT4 / BT4 method) in Croatia were used. The proportional differences in log somatic cell count, and $\operatorname{logSCC}($ in $\%)$ in subsequent milk recordings $\left(1^{\text {st }}\right.$, and $\left.2^{\text {nd }}\right)$ were determined in cows with a significant decrease in daily milk yield at a set temperature-humidity index, THI threshold $(68,72$, and 76$)$. The results indicate high variability in somatic cell count due to the animal's response to heat stress (heat stressed at THI in 68, 72, and 76), parity (1,2, and $3+$ ), breed (Holstein, and Simmental) and breeding region (Central, and Eastern Croatia). Also, it could be pointed out that Holsteins, especially cows in higher parities $(2,3+)$ reared in Eastern Croatia were shown to be more sensitive to environmental stress, even in the period after heat stress $\left(1^{\text {st }}\right.$, and $2^{\text {nd }}$ subsequent milk recording). Since SCC is not only an indicator for mastitis, but also reflects a cow's immune response to general stress situations, the high variability determined may be explained by the individual adaptation capabilities of these two breeds to breeding conditions in the analysed regions.

Key words: dairy cattle; Holstein; Simmental; somatic cell count; heat stress

\section{Introduction}

We are currently living and producing in the world that is rapidly changing. One of the most prominent changes is a climate change (IPCC, 2007). For agriculture and livestock production, this change means, in most cases, deterioration of the environmental effect in numerous regions globally, and consequently a significant effect on livestock production in the world. This is also supported by the forecasts by BATTISTI and NAYLOR (2009), which stated that most of the world will be exposed to median temperatures in the summer that will be higher than the highest recorded temperatures by 2050. Furthermore, REICZIGEL et al. (2009) indicated an increase in heat stress days/year (temperature-humidity index, THI $>68$ ) from 5 to 17 over a period of 30 years in Hungary. GAULY et al. (2013) emphasized that, in the light of global warming, the heat stress of high-producing dairy

\footnotetext{
*Corresponding author:

Maja Gregić, PhD, Department for Animal Production and Biotechnology, Faculty of Agrobiotechnology, Vladimira Preloga 1, 31000 Osijek, Phone: +385 31554 922; E-mail: mgregic@fazos.hr
} 
cows will cause significant problems to European milk producers. SEGNALINI et al. (2013) point out the necessity of the development of adequate adaptation strategies aimed at reducing the negative effects of warming in farm animals in the Mediterranean region. According to DUNN et al. (2014), the problem of global warming will also affect farmers in the UK, meaning an increase in heat stress day frequency from an average 1-2 per year to over 20 per year by 2100 . Modern livestock production most frequently implies high production per animal, meaning high milk production per cow in terms of dairy cattle production. According to HANSEN (2013), the increase in production makes cows more susceptible to heat stress, meaning that heat stress will become an acute problem regardless of climate changes, that will only further exacerbate this problem. High-producing dairy cows lose the ability to regulate their body temperature when the ambient temperatures reach $25-29{ }^{\circ} \mathrm{C}$. This means that heat stress affects high-producing cows much more than low-producing ones (BOHMANOVA, 2006; COLLIER et al., 2006). KADZERE et al. (2002) indicated that the intensive genetic selection for high milk production has resulted in changed thermoregulation physiology, meaning that high-producing cows have larger frames, and consequently larger gastrointestinal tracts that enable them to digest more feed. This creates more metabolic heat and it reduces the ability of cows to regulate their normal temperature in heat stress conditions. Finally, by increasing milk yield, feed intake and metabolic heat, the thermoneutrality of animal shifts to lower temperatures. This also confirms the research of BERMAN (2005) which indicated that an increase in daily milk yield from 35 to $45 \mathrm{~kg} / \mathrm{d}$ results in higher sensitivity to thermal stress and reduces the threshold temperature for intermediate heat stress by $5{ }^{\circ} \mathrm{C}$. According to many studies, a heat stress environment induces a reduction in dry matter intake, milk production (WEST et al., 1999; CASA and RAVELO, 2003, GANTNER et al., 2017) and reproductive performance (BOHMANOVA et al., 2007; RAVAGNOLO et al., 2000). Heat stress conditions also affect the milk composition, somatic cell count (SCC) and mastitis frequency (BOURAOUI et al., 2002; COLLIER and HALL, 2012; CORREACALDERON et al., 2004; GANTNER et al., 2011, 2017; RAVAGNOLO et al., 2000; ST-PIERRE et al., 2003; WEST, 2003; HAMMAMI et al., 2013; SMITH et al., 2013). According to ST-PIERRE et al. (2003), in the USA yearly profit losses due to heat stress conditions amount to between $\$ 897$ - $\$ 1,500$ million. Heat stress may be expressed in many ways while, in dairy cattle, the temperature-humidity index (THI) is the most common measurement that takes into account the ambient temperature and relative humidity (KIBLER, 1964). According to BERNABUCCI et al. (2010) and COLLIER and HALL (2012) milk production is affected by heat stress at THI $=68$, BOURAOUI et al. (2002) set the threshold value at 69, while DU PREEZ et al. (1990a, b) determined that heat stress affects milk production and feed intake when THI values exceed 72. Furthermore, VITALI et al. (2009) stated that the risk of cows dying increases when THI reaches 80. In Croatia, a considerable decrease in daily milk traits was also detected due to a heat stress environment (GANTNER et al., 2011). There are many methods for reducing heat stress: short-term, such as shading, cooling and nutrition (VALTORTA et al., 1997; KADZERE et al., 2002; WEST, 2003), and long-term, that is, selection for heat stress resistance (BOHMANOVA, 2006). The antagonistic relationship between the cow's production and heat tolerance implies the deleterious effect of selection for productivity on the cow's resistance to heat stress (RAVAGNOLO et al., 2000). An unfavourable genetic relationship between THI and productive and reproductive traits in dairy cattle has been also determined (RAVAGNOLO and MISZTAL, 2002a, 2002b; FREITAS et al., 2006; AGUILAR et al., 2009). However, high-producing Holsteins in Israel illustrate that selection for production can be successful in a heat stress environment (AHARONI et al., 1999). The focus of most research into heat stress has been on Holsteins, while only a few studies have compared milk production of Jersey or Simmental and Holstein breeds in terms of heat stress (HARRIS et al., 1960; COLLIER et al., 1981; SMITH et al., 2013; GANTNER et al., 2017). Furthermore, only a few studies have analysed the persistence of heat stress in dairy cattle (JOHNSON et al., 1962; GANTNER et al., 2019).

Taking into consideration the high variability in animals' responses to a heat stress environment, the aim of this research was to determine the effect of the response to heat stress, parity, breed and breeding region on somatic cell count in dairy cattle. 


\section{Materials and methods}

For statistical analysis, the individual test-day records of dairy cows were used collected from 2005 to 2012 as part of regular milk recording (AT4 / BT4 method) in Croatia. Measurements (milk yield, ambient temperature and relative humidity) and milk sampling were performed alternately, at the evening or morning milking. The daily temperature-humidity index (THI) as a measure of heat stress was calculated using the equation by KIBLER (1964):

$\mathrm{THI}=1.8 \times \mathrm{Ta}-(1-\mathrm{RH}) \times(\mathrm{Ta}-14.3)+32$, where $\mathrm{Ta}$ is the average temperature in degrees Celsius, and $\mathrm{RH}$ is relative humidity as a fraction of the unit.

According to the logical control of data, testday records were deleted from the dataset with age at first calving lower than 21 and higher than 36 months, a lactation stage lower than 6 days and higher than 305 days, missing or parity higher than 7 (Simmentals) or 6 (Holsteins), and missing or nonsense $\mathrm{Ta}$ and $\mathrm{RH}$ values. According to parity, the animals were divided into three groups: 1,2 and $3+$. According to the location of the farm, the test-day records were divided into two breeding regions: Central and Eastern Croatia. Furthermore, only cows with a minimum of three test day records per parity were statistically analysed. The data, provided by the Croatian Agricultural Agency, after logical control, consisted of 735,605 testday records from 55,543 Holsteins and 1,101,938 test-day records from 80,069 Simmentals reared in Croatia.

The variability of daily milk yield due to heat stress was tested by least square analyses of variance for each given THI value $(68,72$, and 76$)$ in relation to the breed (Simmental, Holstein), separately for each parity class $(1,2,3+)$, and using the PROC MIXED procedure in SAS (SAS Institute Inc., 2000). The following mixed model was used:

$$
\mathrm{y}_{\mathrm{ijklmn}}=\mathrm{i}+\mathrm{b}_{1}\left(\mathrm{~d}_{\mathrm{i}} / 305\right)+\mathrm{b}_{2}\left(\mathrm{~d}_{\mathrm{i}} / 305\right)^{2}+\mathrm{b}_{3} \mathrm{~h}\left(305 / \mathrm{d}_{\mathrm{i}}\right)+\mathrm{b}_{4} \mathrm{~h}^{2}\left(305 / \mathrm{d}_{\mathrm{i}}\right)+\mathrm{S}_{\mathrm{j}}+\mathrm{A}_{\mathrm{k}}+\mathrm{R}_{1}+\mathrm{T}_{\mathrm{m}}+\mathrm{e}_{\mathrm{ijklmn}}
$$

where:

$\mathrm{y}_{\mathrm{ijklm}}=$ estimated daily milk trait;

$\mu=$ intercept;

$\mathrm{b}_{1}, \mathrm{~b}_{2}, \mathrm{~b}_{3}, \mathrm{~b}_{4}=$ regression coefficients; $\mathrm{d}_{\mathrm{i}}=$ days in milk ( $\mathrm{i}=6$ to 305 day);

$\mathrm{S}_{\mathrm{j}}=$ fixed effect of calving season class $\mathrm{j}(\mathrm{j}=1 / 2005$ to $12 / 2012$ );

$\mathrm{A}_{\mathrm{k}}=$ fixed effect of age at calving class $\mathrm{k}(\mathrm{k}=21$ to 36 month) *only for $1^{\text {st }}$ parity,

$\mathrm{R}_{1}=$ fixed effect of region $1(\mathrm{l}=$ Central, and Eastern Croatia),

$\mathrm{T}_{\mathrm{m}}=$ fixed effect of THI class $(\mathrm{m}=0$ (normal condition - values under the given threshold) or $\mathrm{m}=1$ (heat stress condition - values equal and above the given threshold)),

$\mathrm{e}_{\mathrm{ijklm}}=$ residual.

The significance of the differences between the THI classes was tested by $t$-test. Only cows with a detected statistically significant decrease in daily milk yield (those that were producing in heat stress conditions (test-day records with $\mathrm{THI}=1$ ) with daily milk yield lower than LS-means + STDERR when $\mathrm{THI}=1$ ) were included in the further analyses. The $\log$ somatic cell count $(\operatorname{logSCC})$ on the recording day when heat stress occurred (for each given THI value $(68,72,76))$ was used as the reference level. The proportional difference in $\operatorname{logSCC}$ was determined from the $1^{\text {st }}$ (test-day records measured within 35 days) and $2^{\text {nd }}$ (test-day records measured between 35 and 70 days) subsequent milk recording after heat stress. Furthermore, only subsequent test-day records with $\mathrm{THI}=0$ were taken into account. The proportional difference in $\operatorname{logSCC}$ was determined with regard to the response to heat stress, parity, breed and breeding region. 


\section{Results}

The proportional differences in $\operatorname{logSCC}$ (in \%) in subsequent milk recordings $\left(1^{\text {st }}\right.$, and $\left.2^{\text {nd }}\right)$ after heat stress regarding response to heat stress (THI in $68,72,76)$, parity $(1,2,3+)$, breed (Simmental, Holstein) and breeding region (Central, and Eastern Croatia) are presented in Tables 1 - 3 .

In the first parity Simmentals reared in Central Croatia, that experienced a statistically significant decrease in daily milk yield at THI $\geq 68$ (Table 1), the proportional differences in $\operatorname{logSCC}$ in the $1^{\text {st }}$ subsequent milk recording (SMR) was less than $0.5 \%$ and positive, while in the $2^{\text {nd }}$ subsequent milk recording, the amount of difference was similar but negative. Slightly higher values, but the same trend, were also determined in $1^{\text {st }}$ parity Simmentals reared in Eastern Croatia. In the $1^{\text {st }}$ parity Holsteins, at the $1^{\text {st }}$ SMR, an increase in $\operatorname{logSCC}$ was determined in both regions, with a higher increase in cows reared in the Eastern region. Furthermore, at the $2^{\text {nd }}$ SMR in animals reared in the Central region, a decrease in $\operatorname{logSCC}$ was determined, while in animals reared in the Eastern region, an increase of $0.84 \%$ was observed. Simmentals in $2^{\text {nd }}$ parity, reared in the Central region had a low increase in $\operatorname{logSCC}$ in both SMRs, while in the same breed reared in the Eastern region, a decrease in $\operatorname{logSCC}$ was determined at both milk recordings. In Simmentals in $3+$ parity, the proportional differences in $\operatorname{logSCC}$ were positive and higher than in $1^{\text {st }}$ and $2^{\text {nd }}$ parities. with a higher increase in $2^{\text {nd }}$ SMR. Holsteins in higher parities $(2,3+)$, in both regions, had higher increases in $\operatorname{logSCC}$ in comparison to the Simmental breed. Also, the proportional differences in $\operatorname{logSCC}$ in Holsteins was higher in higher parities and in animals bred in Eastern Croatia.

Table 1. Proportional differences in $\operatorname{logSCC}$ (in \%) in subsequent milk recordings after heat stress in relation to parity $(1,2,3+)$, breed (Simmental, Holstein) and breeding region (Central, and Eastern) when THI $\geq 68$

\begin{tabular}{|l|c|c|c|c|c|c|c|}
\hline \multirow{2}{*}{ Breed } & \multirow{2}{*}{$\begin{array}{c}\text { Region } / \\
\text { Parity }\end{array}$} & 1 & \multicolumn{2}{|c|}{$1^{\text {st }}$ milk recording after heat stress } & \multicolumn{2}{|c|}{$2^{\text {nd }}$ milk recording after heat stress } \\
\cline { 3 - 8 } & & 1 & 2 & $3+$ & 1 & 2 & $3+$ \\
\hline $\begin{array}{l}\text { Simmental } \\
\mathrm{n}=115.662\end{array}$ & Central & +0.276 & +0.164 & +0.278 & -0.232 & +0.017 & +0.588 \\
\cline { 2 - 9 } & Eastern & +0.307 & -0.232 & +0.328 & -0.453 & -0.268 & +0.470 \\
\hline $\begin{array}{l}\text { Holstein } \\
\mathrm{n}=80.208\end{array}$ & Central & +0.175 & +0.311 & +0.488 & -0.134 & +0.328 & +0.711 \\
\cline { 2 - 9 } & Eastern & +0.428 & +0.920 & +1.267 & +0.840 & +1.585 & +1.995 \\
\hline
\end{tabular}

Table 2. Proportional differences in $\operatorname{logSCC}$ (in \%) in subsequent milk recordings after heat stress in relation to parity $(1,2,3+)$, breed (Simmental, Holstein) and breeding region (Central, and Eastern) when THI $\geq 72$

\begin{tabular}{|c|c|c|c|c|c|c|c|}
\hline \multirow[b]{2}{*}{ Breed } & \multirow{2}{*}{$\begin{array}{c}\text { Region / } \\
\text { Parity }\end{array}$} & \multicolumn{3}{|c|}{$1^{\text {st }}$ milk recording after heat stress } & \multicolumn{3}{|c|}{$2^{\text {nd }}$ milk recording after heat stress } \\
\hline & & 1 & 2 & $3+$ & 1 & 2 & $3+$ \\
\hline \multirow{2}{*}{$\begin{array}{l}\text { Simmental } \\
n=91.631\end{array}$} & Central & +0.338 & +0.002 & +0.108 & +0.335 & +0.161 & +0.587 \\
\hline & Eastern & +0.409 & +0.184 & -0.198 & +0.354 & +0.336 & +0.224 \\
\hline \multirow{2}{*}{$\begin{array}{l}\text { Holstein } \\
n=63.775\end{array}$} & Central & +0.130 & +0.056 & +0.488 & -0.094 & +0.129 & +0.685 \\
\hline & Eastern & +0.709 & -0.469 & +1.452 & +0.978 & +1.498 & +1.984 \\
\hline
\end{tabular}

The primiparous cows of both breeds bred in both regions that experienced a statistically significant decrease in daily milk yield when THI $\geq 72$ (Table 2), had similar trends, but higher proportional differences in $\log \mathrm{SCC}$ in the $1^{\text {st }} \mathrm{SMR}$ compared to less heat stress resistant cows (heat stressed at lower THI value, Table 1 ). At the $2^{\text {nd }}$ SMR, a decrease in $\log \mathrm{SCC}$ was only determined in primiparous Holsteins reared in the Central region, while in other animals the increase was determined. In all older cows (2, and $3+$ parity), the proportional differences in $\operatorname{logSCC}$ were positive, with the exception of Simmentals in 3+ parity reared in the Eastern region at the $1^{\text {st }} \mathrm{SMR}$. Furthermore, the highest increase in $\operatorname{logSCC}$ was determined in 3+ parity Holstens in Eastern Croatia at the $2^{\text {nd }}$ SMR. 
V. Gantner et al.: The differences in somatic cell count in dairy cattle in terms of heat stress

Table 3. Proportional differences in $\operatorname{logSCC}$ (in \%) in subsequent milk recordings after heat stress in relation to parity $(1,2,3+)$, breed (Simmental, Holstein) and breeding region (Central, and Eastern) when THI $\geq 76$

\begin{tabular}{|c|c|c|c|c|c|c|c|}
\hline \multirow{2}{*}{ Breed } & \multirow{2}{*}{$\begin{array}{c}\text { Region / } \\
\text { Parity }\end{array}$} & \multicolumn{2}{|c|}{$1^{\text {st }}$ milk recording after heat stress } & \multicolumn{2}{|c|}{$2^{\text {nd }}$ milk recording after heat stress } \\
\cline { 3 - 8 } & 1 & 2 & $3+$ & 1 & 2 & $3+$ \\
\hline Simmental & Central & +0.403 & -0.110 & -0.476 & -1.021 & -0.165 & +0.169 \\
\cline { 2 - 8 } $\mathrm{n}=59.312$ & Eastern & +0.118 & -0.336 & -0.305 & -0.126 & -0.242 & +0.047 \\
\hline \multirow{2}{*}{$\begin{array}{c}\text { Holstein } \\
\mathrm{n}=43.214\end{array}$} & Central & -0.257 & +0.107 & +0.433 & -0.395 & -0.066 & +0.475 \\
\cline { 2 - 8 } & Eastern & +0.223 & +0.980 & +1.693 & +1.187 & +1.391 & +2.097 \\
\hline
\end{tabular}

The animals heat stressed when THI $\geq 76$, had higher variability in $\operatorname{logSCC}$ in relation to parity, breed and breeding region. In Simmentals, an increase in $\operatorname{logSCC}$ was determined in primiparous at $1^{\text {st }} \mathrm{SMR}$, and in $3+$ parity at $2^{\text {nd }} \mathrm{SMR}$. In other Simmentals, a decrease was determined. In Holsteins, at $1^{\text {st }}$ SMR an increase in $\operatorname{logSCC}$ was determined regardless of the parity and region,

\section{Discussion}

In the last few decades, many studies have dealt with the influence of heat stress on the performance of dairy cattle from a phenotypic or genetic point of view. Also, there are many factors (breed, parity, productivity, region, and individual characteristics) affecting an animal's response to a heat stress environment. A lower tolerance to an environment characterised by heat stress in Holsteins compared to other breeds (Jersey, Brown Swiss, or Simmental) in terms of daily milk yield has been suggested by many studies (BIANCA, 1965; COLLIER et al., 1981; SMITH et al., 2013; GANTNER et al., 2017). Also, the significant effect of region and housing system was proven by the research of BOHMANOVA et al. (2007), GANTNER et al. (2011), BRÜGEMANN et al. (2012) and LAMBERTZ et al. (2014). A decrease in daily milk contents (fat and protein) due to heat stress was observed by RODRIGEZ et al. (1985), BOURAOUI et al. (2002), KADZERE et al. (2002), GANTNER et al. (2011), and LAMBERTZ et al. (2014). Contrariwise, KNAPP and GRUMMER (1991) concluded that there was no noticeable drop in fat content in dairy cows under heat stress. Furthermore, JOHNSON et al. (1962) in an analysis of the persistence of the effects of heat stress, with the exception of the primiparous in Central Croatia. Furthermore, at $2^{\text {nd }}$ SMR, a decrease was determined in cows bred in the Central region in $1^{\text {st }}$ and $2^{\text {nd }}$ parities, while in the other groups $\operatorname{logSCC}$ increased. In Holsteins in Eastern Croatia, an increase was determined in all parities and at both SMRs, with the highest increase in cows in $3+$ parity.

discovered that once the hot season was over, the productivity of high-producing cows did not return to normal since the energy deficit could not be fully restored.

Furthermore, similarly as in this research, numerous studies point out the variability in milk somatic cell count (SCC) and mastitis frequency in dairy cows in terms of heat stress (BOURAOUI et al., 2002; COLLIER and HALL, 2012; BRÜGEMANN et al., 2012; CORREACALDERON et al., 2004; GANTNER et al., 2011, 2017, 2019; RAVAGNOLO et al., 2000; STPIERRE et al., 2003; WEST 2003; HAMMAMI et al., 2013; SMITH et al., 2013, LAMBERTZ et al., 2014). BOURAOUI et al. (2002) in their study on dairy cows in a Mediterranean climate determined a negative correlation $(\mathrm{r}=-0.76)$ between daily THI and milk yield, as well as the negative effects of heat stress on daily SCC with increased SCC during the summer compared to the spring period. SMITH et al. (2013), on the basis of a comparison of Holstein and Jersey breed in terms of heat stress, regarding milk yields and somatic cell score (SCS), concluded that Jersey cows seemed to be more heat tolerant than Holsteins. LAMBERTZ et al. (2014) in an analysis of climatic effects on 
milk production traits and somatic cell score in lactating Holstein-Friesian cows, regardinghousing systems, found a positive correlation between THI and somatic cell score (SCS). BRÜGEMANN et al. (2012) determined lower heat stress thresholds than in other international studies, which could be explained by the lower level of adaption of German Holstein cows to a heat stress environment. They also determined that both heat and cold stress had a negative impact on daily SCS. GANTNER et al (2019), in their analysis of persistence of the effects of heat stress, determined an increase of SCC in more heat stress sensitive Holsteins, indicating that Holstein cows, in terms of heat stress, also become more susceptible to mastitis.

On the basis of the analysis performed, the high variability in somatic cell count due to the animal's response to heat stress (heat stressed at THI in 68, 72 , and 76), parity $(1,2$, and $3+)$, breed (Holstein, and Simmental) and breeding region (Central, and Eastern Croatia) should be pointed out. Generally, it could be emphasized that Holsteins reared in Eastern Croatia had higher and positive proportional differences in logSCC (in \%) in both subsequent milk recordings (SMR), implicating higher sensitivity even in the period after heat stress.

Since the SCS is not only an indicator trait for mastitis (PHILIPSSON et al., 1995), but also reflects a cow's immune response to general stress situations (COFFEY et al., 1986), the high variability determined may be explained by the individual adaptation capabilities of both breeds to breeding conditions in the analysed regions.

\section{References}

AGUILAR, I., I. MISZTAL, S. TSURUTA (2009): Genetic components of heat stress for dairy cattle with multiple lactation. J. Dairy Sci. 92, 5702-5711.

DOI: $10.3168 /$ jds.2008-1928

AHARONI, Y., A. BROSH, E. EZRA (1999): Effect of heat load and photoperiod on milk yield and composition in three dairy herds in Israel. Anim. Sci. 69, 37-47.

DOI: $10.1017 / \mathrm{S} 1357729800051079$

BATTISTI, D. S., R. L. NAYLOR (2009): Historical warnings of future food insecurity with unprecedented seasonal heat. Science. 323, 240-244.

DOI: $10.1126 /$ science. 1164363
BERMAN, A. (2005): Estimates of heat stress relief needs for Holstein dairy cows. J. Anim. Sci. 83, 1377-1384.

DOI: $10.2527 / 2005.8361377 \mathrm{x}$

BERNABUCCI, U., N. LACETERA, L. H. BAUMGARD, R. P. RHOADS, B. RONCHI, A. NARDONE (2010): Metabolic and hormonal acclimation to heat stress in domestic ruminants. Animal, 4, 1167-1183.

DOI: $10.1017 / \mathrm{S} 175173111000090 \mathrm{X}$

BIANCA, W. (1965): Reviews of the progress of dairy science. Section A. Physiology. Cattle in a hot environment. J. Dairy Res. 32, 291-345.

DOI: $10.1017 / \mathrm{S} 0022029900018665$

BOHMANOVA, J. (2006): Studies on genetics of heat stress in US Holsteins. PhD thesis, University of Georgia, Athens, GA, USA.

BOHMANOVA, J., I. MISZTAL, J. B. COLE (2007): Temperature-humidity indices as indicators of milk production losses due to heat stress. J. Dairy Sci. 90, 19471956.

DOI: $10.3168 /$ jds.2006-513

BOURAOUI, R., M. LAHMAR, A. MAJDOUB, A. DJEMALI, R. BELYEA (2002): The relationship of temperature humidity-index with milk production of dairy cows in a Mediterranean climate. Anim. Res. 51, 479-491.

DOI: 10.1051/animres:2002036

BRÜGEMANN, K., E. GERNAND, V. KÖNIG, U. BORSTEL, S. KÖNIG (2012): Defining and evaluating heat stress thresholds in different dairy cow production systems. Archiv Tierzucht, 55, 1, 13-24.

DOI: $10.5194 / \mathrm{aab}-55-13-2012$

CASA, A. C., A. C. RAVELO (2003): Assessing temperature and humidity conditions for dairy cattle in Cordoba, Argentina. Int. J. Biometeorol. 48, 6-9.

DOI: $10.1007 / \mathrm{s} 00484-003-0179-\mathrm{x}$

COFFEY, E. M, W. E VINSON, R. E PEARSON (1986): Potential of somatic cell concentration in milk as a sire selection criterion to reduce mastitis in dairy cattle. J. Dairy Sci. 69, 2163-2172.

DOI: $10.3168 /$ jds.S0022-0302(86)80649-X

COLliER, R. J., R. M. ELEY, A. K. SHARMA, R. M. PEREIRA, D. E. BUFFINGTON (1981): Shade management in subtropical environment for milk yield and composition in Holstein and Jersey cows. J. Dairy Sci. 64, 844-849.

DOI: $10.3168 /$ jds.S0022-0302(81)82656-2

COLLIER, R. J., G. E. DAHL, M. J. VAN BAALE (2006): Major advances associated with environmental effects on dairy cattle. J. Dairy Sci. 89, 1244-1253.

DOI: $10.3168 /$ jds.S0022-0302(06)72193-2

COLLIER, R. J., L. W. HALL (2012): Quantifying Heat Stress and Its Imp act on Metabolism and Performance. Department of Animal Sciences. University of Arizona 74-84. 
CORREA-CALDERON, A., D. ARMSTRONG, D. RAY, S. DE NISE, M. ENNS, C. HOWISON (2004): Thermoregulatory responses of Holstein and Brown Swiss heat-stressed dairy cows to two different cooling systems. Int. J. Biometeorol. 48, 142-148.

DOI: $10.1007 / \mathrm{s} 00484-003-0194-\mathrm{y}$

DUNN, R. J. H., N. E. MEAD, K. M. WILlETT, D. E. PARKER (2014): Analysis of heat stress in UK dairy cattle and impact on milk yields. Environ. Research Letters 9, 064006 (11pp).

DOI: $10.1088 / 1748-9326 / 9 / 6 / 064006$

DU PREEZ, J. H., W. H. GIESECKE, P. J. HATTINGH (1990a): Heat stress in dairy cattle and other livestock under Southern African conditions. I. Temperaturehumidity index mean values during the four main seasons. Onderstepoort J. Vet. Res. 57, 77-86.

DU PREEZ, J. H., P. J. HATTING, W. H. GIESECKE, B. E. EISENBERG (1990b): Heat stress in dairy cattle and other livestock under Southern African conditions. III. Monthly temperature-humidity index mean values and their significance in the performance of dairy cattle. Onderstepoort J. Vet. Res. 57, 243-248.

FREITAS, M., I. MISZTAL, J. BOHMANOVA, R. TORRES (2006): Regional differences in heat stress in US Holsteins. Proceedings $8^{\text {th }}$ World Congress Genet. Appl. Livest. Prod. Commun. 01-11. Istituto Prociencia, Belo Horizonte, Brazil.

GANTNER, V., P. MIJIĆ, K. KUTEROVAC, D. SOLIĆ, R. GANTNER (2011): Temperature-humidity index values and their significance on the daily production of dairy cattle. Mljekarstvo 61, 1, 56- 63.

DOI: 10.3920/978-90-8686-741-7_8

GANTNER, V., T. BOBIĆ, R. GANTNER, M. GREGIĆ, K. KUTEROVAC, J. NOVAKOVIĆ, K. POTOČNIK (2017): Differences in response to heat stress due to production level and breed of dairy cows. Int. J. Biometeorol. 61, 9, 1675-1685.

DOI: $10.1007 / \mathrm{s} 00484-017-1348-7$

GANTNER, V., T. BOBIĆ, K. POTOČNIK, M. GREGIĆ, D. KUČEVIĆ (2019): Persistence of heat stress effect in dairy cows. Mljekarstvo 69 1, 30-41.

DOI: $10.15567 / \mathrm{mljekarstvo.2019.0103}$

GAULY, M., H. BOLLWEIN, G. BREVES, K. BRÜGEMANN, S. DÄNICKE, G. DAS, J. DEMELER, H. HANSEN, J. ISSELSTEIN, S. KÖNIG, M. LOHÖLTER, M. MARTINSOHN, U. MEYER, M. POTTHOFF, C. SANKER, B. SCHRÖDER, N. WRAGE, B. MEIBAUM, G. VON SAMSON-HIMMELSTJERNA, H. STINSHOFF, C. WRENZYCKI (2013): Future consequences and challenges for dairy cow production systems arising from climate change in Central Europe - a review. Animal 7, 843-859.

HAMMAMI, H., J. BORMANN, N. M'HAMDI, H. H. MONTALDO, N. GENGLER (2013): Evaluation of heat stress effects on production traits and somatic cell score of Holsteins in a temperate environment. J. Dairy Sci. 96, 1844-1855.

DOI: $10.1017 / \mathrm{S} 1751731112002352$

HANSEN, P. J. (2013): Genetic Control of Heat Stress in Dairy Cattle. Proceedings $49^{\text {th }}$ Florida Dairy Production Conference, Gainesville, April 10, 2013.

HARRIS, D. L., R. R. SHRODE, I. W. RUPEL, R. E. LEIGHTON (1960): A study of solar radiation as related to physiological and production responses of lactating Holstein and Jersey cows. J. Dairy Sci. 43, 1255-1262.

DOI: 10.3168/jds.S0022-0302(60)90312-X

IPCC - INTERGOVERNMENTAL PANEL ON CLIMATE CHANGE - IPCC: CLIMATE CHANGE 2007 (2007): The Physical Science Basis. Contribution of Working Group I to the Fourth Assessment Report of the Intergovernmental Panel on Climate Change. Cambridge University Press, Cambridge/New York, NY, USA.

JOHNSON, H. D., A. C. RAGSDALE, I. L. BERRY, M. D. SHANKLIN (1962): Effect of various temperature humidity combinations on milk production of Holstein cattle. Res. Bull. Missouri Agric. Exp. Station, 791.

KADZERE, C. T., M. R. MURPHY, N. SILANIKOVE, E. MALTZ (2002): Heat Stress in Lactating Dairy Cows: A Review. Livest. Prod. Sci. 77, 59-91.

DOI: 10.1016/S0301-6226(01)00330-X

KIBLER, H. H. (1964): Environmental physiology and shelter engineering. LXVII. Thermal effects of various temperature-humidity combinations on Holstein cattle as measured by eight physiological responses, Res. Bull. Missouri Agric. Exp. Station, 862.

KNAPP, D. M., R. R. GRUMMER (1991): Response of lactating dairy cows to fat supplementation during heat stress. J. Dairy Sci. 74, 2573-2579.

DOI: $10.3168 /$ jds.S0022-0302(91)78435-X

LAMBERTZ, C., C. SANKER, M. GAULY (2014): Climatic effects on milk production traits and somatic cell score in lactating Holstein-Friesian cows in different housing systems. American Dairy Science Association. J. Dairy Sci. 97, 319-329.

DOI: $10.3168 /$ jds.2013-7217

PHILIPSSON, J., G. RAL, B. BERGLUND (1995): Somatic cell count as a selection criterion for mastitis resistance in dairy cattle. Livest. Prod. Sci. 41, 195-200.

DOI: 10.1016/0301-6226(94)00067-H

RAVAGNOLO, O., I. MISZTAL, G. HOOGENBOM (2000): Genetic component of heat stress in dairy cattle, development of heat indeks function. J. Dairy Sci. 83, 2120-2125.

DOI: $10.3168 /$ jds.S0022-0302(00)75094-6

RAVAGNOLO, O., I. MISZTAL (2000a): Studies on genetics of heat tolerance in dairy cattle with reduced weather information via cluster analysis. J. Dairy Sci. 85, 1586-1589. DOI: 10.3168/jds.S0022-0302(02)74228-8 
RAVAGNOLO, O., I. MISZTAL (2000b): Effect of heat stress on nonreturn rate in Holstein cows: Genetic analysis. J. Dairy Sci. 85, 3092-3100.

DOI: $10.3168 /$ jds.S0022-0302(02)74396-8

REICZIGEL, J., N. SOLYMOSI, L. KÖNYVES, A. MARÓTIAGÓTS, A. KERN, J. BARTYIK (2009): Examination of heat stress caused milk production loss by the use of temperature-humidity indices. Magy Allatorv, 131, 137-144.

RODRIGUEZ, L. W., G. MEKONNEN, C. J. WILCOX, F. G. MARTIN, W. A. KRIENK (1985): Effects of relative humidity, maximum and minimum temperature, pregnancy and stage of lactation on milk composition and yield. J. Dairy Sci. 68, 973-978.

DOI: $10.3168 /$ jds.S0022-0302(85)80917-6

SAS USER'S GUIDE (2000): Version 8.2 Edition. SAS Institute Inc. Cary, NC.

SEGNALINI, M., U. BERNABUCCI, A. VITALI, A. NARDONE, N. LACETERA (2013): Temperature humidity index scenarios in the Mediterranean basin. Int. J. Biometeorol. 57, 451-458.

DOI: $10.1017 / \mathrm{S} 2040470010000282$

SMITH, D. L., T. SMITH, B. J. RUDE, S. H. WARD (2013): Short communication: Comparison of the effects of heat stress on milk and component yields and somatic cell score in Holstein and Jersey cows. J. Dairy Sci. 96, 3028-3033.

DOI: $10.3168 /$ jds.2012-5737
ST-PIERRE, N. R., B. COBANOV, G. SCHNITKEY (2003): Economic losses from heat stress by US livestock industries. J. Dairy Sci. 86, 52-77.

DOI: $10.3168 /$ jds.S0022-0302(03)74040-5

VALTORTA, S. E., P. E. LEVA, M. R. GALLARDO (1997): Evaluation of different shades to improve dairy cattle wellbeing in Argentina. Int. J. Biometeorol. 41, 65-67.

DOI: $10.1007 / \mathrm{s} 004840050055$

VITALI, A., M. SAGNALINI, L. BERTOCCHI, U. BERNABUCCI, A. NARDONE, N. LACTERA (2009): Seasonal pattern of mortality and relationships between mortality and temperature humidity index in dairy cows. J. Dairy Sci. 92, 3781-3790.

DOI: $10.3168 /$ jds.2009-2127

WEST, J. W (2003): Effects of heat-stress on production in dairy cattle. J. Dairy Sci. 86, 2131-2144.

DOI: 10.3168/jds.S0022-0302(03)73803-X

WEST, J. W., G. M. HILL, J. M. FERNANDEZ, P. MANDEBVU, B. G. MULLINIX (1999): Effect of dietary fiber on intake, milk yield, and digestion by lactating dairy cows during cool or hot, humid weather. J. Dairy Sci. 82, 2455-2465.

DOI: $10.3168 /$ jds.S0022-0302(99)75497-4

Received: 17 April 2019

Accepted: 20 August 2019

GANTNER, V., B. MARKOVIĆ, M. GAVRAN, M. ŠPERANDA, D. KUČEVIĆ, M. GREGIĆ, T. BOBIĆ: Utjecaj odgovora na toplinski stres, redoslijeda laktacije, pasmine te regije uzgoja na broj somatskih stanica $u$ mliječnih goveda. Vet. arhiv 90, 435-442, 2020.

\section{SAŽETAK}

U cilju utvrđivanja utjecaja odgovora na toplinski stres, redoslijeda laktacije, pasmine te regije uzgoja na broj somatskih stanica u mliječnih krava analizirani su zapisi na kontrolni dan prikupljeni u periodu od 2005. do 2012. tijekom provedbe redovite kontrole mliječnosti (AT4 / BT4 metoda) u Hrvatskoj. Proporcionalna razlika u $\operatorname{logSCC}$ (\%) u slijedećim kontrolama mliječnosti (1. i 2.), utvrđena je u krava sa znakovitim padom dnevne količine mlijeka pri određenim graničnim vrijednostima THI (68, 72 i 76). Utvrđeni rezultati ukazuju na visoku varijabilnost u broju somatskih stanica uslijed odgovora grla na toplinski stres (u toplinskom stresu pri THI 68, 72 i 76), redoslijeda laktacije (1, 2 i 3+), pasmine (Holstein i Simmental) te regije uzgoja (središnja i istočna Hrvatska). Nadalje, može se istaknuti da su se grla Holstein pasmine, osobito krave u višim laktacijama (2., 3+) uzgajane u istočnoj Hrvatskoj, pokazale kao osjetljivije na stresne okolišne uvjete, čak i u razdoblju nakon toplinskog stresa (1., i 2. kontrola mliječnosti). Budući da broj somatskih stanica ne predstavlja samo indikator mastitisa, već odražava i imunološki odgovor krave na opće stresne situacije, utvrđena visoka varijabilnost može biti objašnjena individualnim adaptacijskim mogućnostima obiju pasmina na uvjete uzgoja u analiziranim regijama.

Ključne riječi: mliječna goveda; Holstein; Simmental; broj somatskih stanica; toplinski stres 